\title{
National Narcissism and the Belief and the Dissemination of Conspiracy \\ Theories During the COVID-19 Pandemic: Evidence From 56 Countries
}

\author{
Anni Sternisko*1 Aleksandra Cichocka ${ }^{2,3}$ Aleksandra Cislak ${ }^{3,4}$ Jay J. Van Bavel*1
}

\section{Addresses}

${ }^{1}$ Department of Psychology, New York University, New York, NY 10003, USA

${ }^{2}$ School of Psychology, University of Kent, CT2 7NZ Canterbury, UK

${ }^{3}$ Institute of Psychology, Nicolaus Copernicus University, Torun, Poland

${ }_{4}^{4}$ SWPS University of Social Sciences and Humanities, Chodakowska 19/31, 03-815, Warsaw, Mazowieckie, Poland

${ }^{5}$ Center for Neural Science, New York University, New York, NY 10003, USA

*Corresponding authors:

Van Bavel, Jay J. (jay.vanbavel@nyu.edu)

Sternisko, Anni (as10039@nyu.edu)

Department of Psychology, New York University, New York, NY 10003, USA

\section{Acknowledgements}

We thank the Social Identity and Morality Lab for valuable feedback on a previous version of this article. We thank Prolific for generously waiving recruitment fees for Study 2 as part of the COVID-19 research initiative. Preparation of this article was supported by the Polish National Science Center grant 2018/29/B/HS6/02826 and the Alliance for Decision Education.

\section{Conflict of interest}

Nothing declared.

\section{Author contributions}

A.S., J.VB., and A.Cic. designed and conducted Study 1. All authors designed and conducted Study 2. All authors coordinated secondary analyses of Study 3. A.S. analyzed data and A.Cic. verified analyses. All authors discussed the results, developed the theoretical framework, and contributed to the final manuscript.

Wordcount: 9,933 (excluding figures and tables) 


\begin{abstract}
Conspiracy theories related to COVID-19 have propagated around the globe, leading the World Health Organization to declare the spread of misinformation an 'Infodemic'. We tested the hypothesis that national narcissism —a belief in the greatness of one's nation that requires external recognition — is associated with the spread of conspiracy theories during the COVID-19 pandemic. In two large-scale national surveys $\left(N_{\text {Total }}=950\right)$ conducted in the US and the UK, and secondary analysis of data from 56 countries $(N=50,757)$, we found a robust, positive relationship between national narcissism and proneness to believe and disseminate conspiracy theories related to COVID-19. Further, belief in COVID-19 conspiracy theories was related to less engagement in health behaviors and less support for public-health policies to combat COVID-19. Our findings illustrate the importance of social identity factors in the spread of conspiracy theories and provide insights into the psychological processes underlying the COVID-19 pandemic. (149 words)
\end{abstract}

Keywords: COVID-19, conspiracy theories, collective narcissism, social identity, public-health 


\begin{abstract}
Conspiracy theories related to COVID-19 have propagated around the globe, leading the World Health Organization to declare the spread of misinformation an 'Infodemic'. We tested the hypothesis that national narcissism — a belief in the greatness of one's nation that requires external recognition — is associated with the spread of conspiracy theories during the COVID-19 pandemic. In two large-scale national surveys $\left(N_{\text {Total }}=950\right)$ conducted in the US and the UK, and secondary analysis of data from 56 countries $(N=50,757)$, we found a robust, positive relationship between national narcissism and proneness to believe and disseminate conspiracy theories related to COVID-19. Further, belief in COVID-19 conspiracy theories was related to less engagement in health behaviors and less support for public-health policies to combat COVID-19. Our findings illustrate the importance of social identity factors in the spread of conspiracy theories and provide insights into the psychological processes underlying the COVID-19 pandemic. (149 words)
\end{abstract}

Keywords: COVID-19, conspiracy theories, collective narcissism, social identity, public-health 


\section{National Narcissism and the Belief and the Dissemination of Conspiracy Theories During the COVID-19 Pandemic: Evidence From 56 Countries}

In a recent joint statement, leading health organizations stressed that managing the 'infodemic' - the overabundance of information - was "a critical part of controlling the COVID19 pandemic" as "Misinformation costs lives" (WHO, 2020). Indeed, conspiracy theories related to COVID-19 are thriving worldwide, risking expediting the pandemic's death toll (Cichocka, 2020; Douglas, 2021). Conspiracy theories constitute the idea that a secret group of people is conspiring towards a malevolent or unlawful goal (Douglas et al., 2019). Since belief in these ideas is relatively immune to standard interventions against misinformation, researchers advise paying special attention to prevention (Jolley \& Douglas, 2017). This paper offers a multinational analysis of potential risk factors underlying the spread of conspiracy theories during a pandemic.

Across 56 countries, we tested our hypothesis that social identity motives - specifically national narcissism - are associated with the spread of COVID-19 conspiracy theories and examined implications for public health. National narcissism is an instance of collective narcissism - the defensive belief in the greatness of one's ingroup that requires external recognition (Golec de Zavala et al., 2009). It is inspired by the concept of individual narcissism, that is feelings of self-importance and entitlement to special treatment (Krizan \& Herlache, 2018). However, collective narcissism is tied to the belief that it is one's ingroup, rather than the self, that is exceptional, deserves special treatment and that others do not sufficiently recognize it (Golec de Zavala, et al., 2019). Although national narcissism (i.e., collective narcissism with regards to one's nation) is assessed as a continuum, for simplicity we refer to people who score high in national narcissism as national narcissists. 
National narcissism partly overlaps with other forms of inflated ingroup positivity as well as with political conservatism but is not identical to these constructs (Cichocka \& Cislak, 2020; Golec de Zavala et al., 2019). National narcissists are primarily concerned with reinforcing an (idealistic) national image and preferential treatment of their nation. In contrast to nationalists, they are less concerned with achieving actual intergroup dominance (see Kosterman \& Feshbach, 1989). The defensive sense of entitlement and preoccupation with external recognition of the ingroup also differentiates national narcissism from political conservatism. Political conservatism is characterized by an investment in national traditions and values, reluctance for change, and support for social hierarchies (Jost et al., 2003). National narcissists, on the other hand, pursue a political agenda that is primarily driven by concerns of what makes their nation look good (Cichocka \& Cislak, 2020; Cislak et al., 2018; Cislak et al., 2021). They care about what the nation can do for them and how it reflects on them (Cichocka, 2016). They are ready for change and are quick to abandon their country if it benefits them (Marchlewska et al., 2020).

National narcissism is also distinguishable from national identification, which can be understood as centrality of national identification to the self, ties to fellow citizens, and satisfaction with one's nation (Cameron, 2004; Leach et al., 2008). National narcissism and national identification tend to overlap as they both assume positive feelings about the national group (Golec de Zavala, Cichocka, \& Bilewicz, 2013; Marchlewska et al., 2020). Once this overlap is accounted for, psychological and behavioral correlates of national narcissism and national identification often diverge. For instance, national identification without the narcissistic, defensive component is related to constructive intra- and intergroup attitudes and behaviors, while national narcissism tends to predict more destructive outcomes like outgroup hostility 
(Golec de Zavala, Cichocka, \& Bilewicz, 2013; see Cichocka, 2016; Cichocka \& Cislak, 2020 for reviews).

\section{National Narcissism and Conspiracy Theories}

The psychological defensiveness characteristic for national narcissists makes them particularly susceptible to conspiracy theories during the current pandemic. National narcissists are hypersensitive to criticism and underappreciation of their nation (Golec de Zavala et al., 2016), more so than nationalists and political conservatives. They rely on outgroup hostility to manage national image threats (Golec de Zavala, Cichocka, \& Iskra-Golec, 2013; Guerra et al., 2020) and tend to blame others for national misfortunes (Cichocka, Marchlewska, Golec de Zavala, \& Olechowski, 2016). In one study, Portuguese national narcissists were more likely to think that Germany is undermining Portugal's standing in Europe and reported greater hostility towards Germans (Golec de Zavala et al., 2016). The image threat sensitivity combined with the tendency to look for external explanations for any national failings may explain why national narcissists are prone to believe that others are plotting against their nation (Cichocka, Marchlewska, Golec de Zavala, \& Olechowski, 2016; Golec de Zavala \& Cichocka, 2012; van Prooijen \& Song, 2020).

Accordingly, past research has linked national narcissism to belief in conspiracy theories. For instance, research conducted in Poland found that greater national narcissism was associated with stronger beliefs that Russia had been conspiring against Poland, even when adjusting for anti-Russian attitudes and political conservatism. After controlling for national narcissism, national identification was negatively related to these beliefs (Cichocka, Marchlewska, Golec de Zavala, \& Olechowski, 2016). Research in the US also found that national narcissism was associated with greater belief that foreign nations are conspiring against the US (van Prooijen \& 
Song, 2020) but was unrelated to a belief in conspiracy theories implying that the US government is conspiring (Cichocka, Marchlewska, \& Golec de Zavala, 2016). In the context of the 2016 US elections, national narcissism was associated with a rise in generalized conspiratorial thinking (Federico \& Golec de Zavala, 2018).

So far, most studies have examined the relationship between national narcissism and conspiracy theory beliefs in the context of managing intergroup conflicts (Biddlestone, Cichocka et al., 2020). Since conspiracy theories seem to primarily emerge from the desire to reinforce an idealistic national image, there is reason to believe that national narcissism is also associated with conspiracy theory beliefs in contexts devoid of a clear out-group enemy. Recent studies have linked national narcissism to conspiracy theories about climate change (Bertin et al., 2021) and medical science (Cislak et al., 2021). For instance, national narcissists were more likely to believe conspiracy theories about vaccinations (Cislak et al., 2021), presumably to bolster the idealistic image of an invulnerable and self-sufficient nation. We investigate whether national narcissism might also predict belief in conspiracy theories about a public-health crisis.

\section{National Narcissism and the Spread of COVID-19 Conspiracy Theories}

Public-health crises constitute existential hazards to the population and may reveal weaknesses in leadership and healthcare to a watching world. As such, they threaten an idealistic national image. National narcissists - more so than others - may experience public-health crises such as the COVID-19 pandemic as a severe identity threat (see Lincoln, 2020). Conspiracy theories about the COVID-19 pandemic might emerge from the desire to manage this threat. COVID-19 conspiracy theories respectively deny (e.g., COVID-19 is a hoax) or deflect (e.g., COVID-19 is a bioweapon) from national failings. They may thus serve to buffer an idealistic national image and fulfill identity needs (Cichocka, Marchlewska, \& Golec de Zavala, 2016; 
Douglas et al., 2017; Sternisko et al., 2020; Van Bavel \& Pereira, 2018). We therefore expected that those who are particularly concerned with defending the national image -national narcissists- should be more prone to believe COVID-19 conspiracy theories.

Furthermore, we argue that national narcissism is associated with the spread of conspiracy theories related to COVID-19. So far, research has mostly focused on how conspiracy theories propagate on a system level (e.g., Gruzd \& Mai, 2020). For instance, false information and conspiracy theories spread faster than true information (Vosoughi et al., 2018; Wood, 2017). However, less is known about who spreads these narratives. Identifying such risk groups is theoretically and practically important. We hypothesized that national narcissist are more ready to disseminate conspiracy theories related to COVID-19, for example as a means to publicly defend the ingroup image and because people find it more acceptable to share misinformation that reinforces their social identities (e.g., Effron, 2018; see also Van Bavel, Harris, et al., 2021).

\section{Health Behaviors and Public Health Policies During the COVID-19 Pandemic}

In addition to investigating social identity processes related to COVID-19 conspiracy theories, our studies explored potential implications of these beliefs for the containment of the pandemic. Conspiracy theories can undermine trust in science (Van der Linden et al., 2020) and government (Einstein \& Glick, 2015) and have been linked to rejection of medical recommendations (Jolley \& Douglas, 2014). Correspondingly, several studies have linked belief in COVID-19 conspiracy theories to the rejection of public health guidelines during the COVID19 pandemic (e.g., Biddlestone, Green, et al., 2020; Marinthe, Brown, et al., 2020, but see also Imhoff \& Lamberty, 2020). Most of these studies, however, were conducted amongst Western societies which raises the question of how generalizable these processes are to other cultures. Across nations, the pandemic has unfolded in different ways and governments varied in their 
response to it. Our paper extends past work, investigating the relationship between COVID-19 conspiracy theories and public health on a global scale.

One may expect that national narcissism is related to the rejection of public health guidelines to the extent that it is related to the belief in COVID-19 conspiracy theories. This would be consistent with findings that belief in COVID-19 conspiracy theories mediates the positive relationship between national narcissism and vaccine hesitancy (Cislak et al., 2021, Hughes \& Machan, 2020). It could also explain why other researchers found no or only weak effects of national narcissism on different health behaviors and attitudes (Van Bavel et al., 2021; see also Nowak et al., 2020). There may be various psychological processes that link national narcissism to health behaviors and attitudes, some of which counteract each other. For instance, national narcissists may be generally motivated to adhere to and implement health guidelines, possibly to signal that their nation is 'exceptionally good' at fighting the pandemic (Gronfeldt et al., 2021). At the same time, their susceptibility to COVID-19 conspiracy theories might lead national narcissists to question the seriousness of the pandemic and the validity of public health recommendations. Therefore, it is important to examine the potential for mediation.

\section{Overview}

This paper offers a multi-national analysis of a potential key risk factor underlying the spread of conspiracy theories and potential implications for public health. In three studies, including two national surveys and a third survey from 56 countries, we examined individualpsychological processes related to conspiracy theory dissemination and to national narcissism outside of intergroup settings.

We pre-registered three key hypotheses. We predicted that national narcissism would be positively associated with belief in COVID-19 conspiracy theories (H1; Studies 1-3). We also 
predicted that national narcissism would be positively associated with intentions to disseminate COVID-19 conspiracy theories (H2; Studies 1 \& 2). Finally, we predicted that the relationship between national narcissism and intentions to disseminate COVID-19 conspiracy theories would be mediated by belief in COVID-19 conspiracy theories (H3; Studies 1 \& 2).

In addition, we had two exploratory research questions. First, we examined whether belief in COVID-19 conspiracy theories is associated with [a] physical hygiene, [b] physical distancing, [c] support for public policies related to COVID-19 (Studies $2 \&$ 3). Second, we explored whether the belief in COVID-19 conspiracy theories might mediate the relationship between national narcissism and health behaviors and policy support (Studies $2 \& 3$ ).

Our studies were designed to test our hypotheses and research questions with high powered samples and probe several potential alternative explanations. To isolate the unique effects of national narcissism, we statistically adjusted for national identification (Studies 1-3), individual narcissism (Study 3), and political ideology (Studies 1 - 3). Further, we distinguished COVID-19 conspiracy theories from conspiracy theories unrelated to COVID-19 and examined the possibility that greater belief and intentions to disseminate COVID-19 conspiracy theories simply reflect greater proneness to believe and disseminate conspiracy theories in general (Study 1). In addition, we found evidence that proneness to believe nonsensical information (i.e., reflexive open-mindedness; Study1), lack of knowledge about the pandemic (Study 2), an inclination to post about COVID-19 (Study 2), and lower reflection about information (Studies 1 \& 3) do not confound our results.

\section{Open Practice Statement}

Study 1 was exploratory. Study 2 was confirmatory (H1 \& H2) and exploratory (Research Questions 1). Hypotheses, study design and analyses of Study 2 were formally pre- 
registered on OSF (https://osf.io/d932p/?view_only=314b71bd74fb4bc9aa9e69b105b36ac7).

Study 3 was confirmatory (H1, Research Question 1). ${ }^{1}$ Hypotheses and analyses of Study 3 were pre-registered on OSF.

(https://osf.io/umtr6/?view_only=8554d300e6e84da48b2b74086ab76215). Research Question 2

(Studies $2 \& 3$ ) and robustness tests on political ideology (Studies 1-3) were added post hoc to

this manuscript and were not pre-registered. Detailed reports of deviations from pre-registrations for each study can be found in the study's pre-registration notes in the Supplement. De-

identified data (Studies $1 \&$ 2), analysis-codes (Studies 1 -3) and study transcripts (Studies 1 \& 2) are available on OSF

(https://osf.io/7vjr2/?view_only=90c6c026c5b74df4bed3297c71661b05). All measures and exclusions in these studies are reported.

\section{Study 1 - United States Survey}

In Study 1, we tested our three main hypotheses. We examined whether national narcissism is associated with stronger belief in COVID-19 conspiracy theories (H1). Further, we investigated whether national narcissism is associated with greater intentions to disseminate COVID-19 conspiracy theories (H2) and whether this relationship is mediated by greater belief in these narratives (H3). We additionally distinguished conspiracy theories that are related to COVID-19 from conspiracy theories that are unrelated to COVID-19. We statistically adjusted for a general proneness to believe and disseminate conspiracy theories, reflexive openmindedness, political ideology, and national identification.

\footnotetext{
${ }^{1}$ In Study 3, we preregistered predictions for health behaviors and attitudes which were based on the results from Study 2. Due to the low psychometric quality of the health behavior measures in Study 2, we registered these predictions with caution, and they are best understood as exploratory research questions.
} 


\section{Methods}

\section{Participants}

In March 2020, we recruited a sample of 300 US adults to participate in an online survey. The sample was stratified over age, gender, and race. Seven participants failed the attention check and were excluded $\left(N_{\text {total }}=293 ; 146\right.$ female, 144 male, 3 other; 25 Asian/Asian American, 47 Black/African American, 200 White/Caucasian American, 21 other; $M_{\text {Age }}=44.41, S D_{\text {Age }}=$ 16.11). Sample size was determined by economic considerations. A post-hoc sensitivity analysis using $G^{*}$ Power 3.1 found that our study was sensitive to detect a medium effect size of Cohen's $f^{2}=0.04$ (Linear multiple regression: Fixed model, $R^{2}$ increase, Type I error $=.05$, Power $=.80$ ). The sample was recruited through Prolific Academic, which ensures high data quality and adequate participant compensation.

\section{Procedure}

Study 1 was conducted online via Qualtrics and approved by the [BLINDED] Institutional Review Board. After signing the consent form, participants responded to a series of scales that were presented in randomized order and reported demographic information. Last, they responded to a simple attention check and were debriefed. Data collection for Study 1 was part of a larger survey that examined various, unrelated research questions and correspondingly included additional measures that were not of interest for the present study (see Supplement).

\section{Measures}

Unless noted otherwise, variables were measured on a 5-point scale with higher numbers reflecting stronger manifestations of the construct. Descriptive statistics for each measure are reported in Table 1. All key scales are reported in Supplement section 1.1. 
National Narcissism. We measured national narcissism with a validated, three-item version (Ardag, 2019) of the Collective Narcissism Scale (Golec de Zavala et al., 2009; e.g., I will never be satisfied until the United States gets the recognition it deserves.)

\section{Belief in and Dissemination Intentions of COVID-19 Conspiracy Theories.}

Participants read a series of conspiracy theories. Eight conspiracy theories were unrelated to COVID-19 (e.g., faked moon-landing). Two conspiracy theories were related to COVID-19: one "deflection conspiracy theory", claiming that the pandemic was a Chinese bioweapon and one “denial conspiracy theory", claiming that the pandemic was a media scheme against the Trump administration.

For each statement, participants first rated their agreement with it $(1=$ strongly disagree to $5=$ strongly agree $)$ and then their intentions to share it online $(1=$ not at all to $5=$ very $m u c h)$. We left it free to the participants whether they would share a supporting or opposing position. Prior work suggests that intentions to share misinformation are highly correlated with actual sharing behavior on social media (Mosleh et al., 2020). Participants further chose from a list of previously evaluated conspiracy theories (related and unrelated to COVID-19) the one they would be most likely to post about online. For exploratory purposes, participants then indicated on which social media platform they would share their beliefs (see Supplement section 1.3 for analyses). Ratings of agreement and dissemination intention with respect to COVID-19 conspiracy theories were averaged to a belief and dissemination intention index, respectively. ${ }^{2}$

\section{Covariates.}

\footnotetext{
2 Conclusions were similar when we analyzed "denial" and "deflection" COVID-19 conspiracy theories separately or used average scores. For separate analyses see Supplement (Tables S.1.2 - S.1.4).
} 
National identification. National identification was assessed with a validated single-item measure: I identify with being American (Postmes et al., 2012).

\section{Belief in and Dissemination Intentions of Conspiracy Theories Unrelated to COVID-}

19. Seven of the eight conspiracy theories that were unrelated to COVID-19 were taken from Douglas et al. (2016) and included ideas like 9/11 was an inside job and that the AIDS virus was created in a laboratory. The additional conspiracy theory claimed that there was a cover-up of the harmful effects of vaccines in general. Ratings of agreement and dissemination intentions for conspiracy theories unrelated to COVID-19 formed reliable scales and were averaged, respectively. ${ }^{3}$

Reflexive Open-Mindedness. Reflexive open-mindedness describes the tendency to quickly and unskeptically accept claims (Pennycook \& Rand, 2018) and was measured via the Bullshit Receptivity Scale (Pennycook et al., 2015).

Political Ideology. Participants rated their political ideology on a 7-point scale from $1=$ Extremely liberal to $7=$ Extremely conservative (Carney et al., 2008).

\section{Analyses and Results}

Participants with missing values on any of the independent and dependent variables were excluded from the analyses. We observed no statistical outliers defined as participants whose responses to the predictors/outcomes of interest (national narcissism, belief in COVID-19 conspiracy theories, intentions to disseminate COVID-19 conspiracy theories) exceeded +-3 Standard Deviations. Zero-order correlations between all measures are reported in Table 1.

\footnotetext{
${ }^{3}$ See Supplement section 1.4 for more psychometric qualities of these scales
} 


\section{Table 1}

Descriptive Statistics and Correlations of Key Variables in Study 1 (United States)

\begin{tabular}{|c|c|c|c|c|c|c|c|c|c|c|c|}
\hline Variable & $a$ & $M$ & $S D$ & 1 & 2 & 3 & 4 & & 5 & 6 & 7 \\
\hline $\begin{array}{l}\text { 1. Belief } \\
\text { COVID-19 } \\
\text { Conspiracy } \\
\text { Theories }\end{array}$ & $r=.45$ & 1.95 & 1.07 & & & & & & & & \\
\hline $\begin{array}{l}\text { 2. Dissemination } \\
\text { COVID-19 } \\
\text { Conspiracy } \\
\text { Theories }\end{array}$ & $r=.72$ & 2.14 & 1.41 & $\begin{array}{l}.35^{*} \\
{[.24, .45]}\end{array}$ & & & & & & & \\
\hline $\begin{array}{l}\text { 3. National } \\
\text { Narcissism }\end{array}$ & .82 & 2.10 & 0.99 & $\begin{array}{l}.48 * \\
{[.38, .56]}\end{array}$ & $\begin{array}{l}.24^{*} \\
{[.13, .35]}\end{array}$ & & & & & & \\
\hline $\begin{array}{l}\text { 4. National } \\
\text { Identification }\end{array}$ & .94 & 3.90 & 1.18 & $\begin{array}{l}.20 * \\
{[.08, .30]}\end{array}$ & $\begin{array}{l}.16^{*} \\
{[.05, .27]}\end{array}$ & $\begin{array}{l}.39 * \\
{[.29, .48]}\end{array}$ & & & & & \\
\hline $\begin{array}{l}\text { 5. Belief other } \\
\text { Conspiracy } \\
\text { Theories }\end{array}$ & .83 & 1.90 & 0.77 & $\begin{array}{l}.60 * \\
{[.52, .67]}\end{array}$ & $\begin{array}{l}.31 * \\
{[.20, .41]}\end{array}$ & $\begin{array}{l}.30 * \\
{[.19, .40]}\end{array}$ & $\begin{array}{l}.01 \\
{[-.10, .13}\end{array}$ & & & & \\
\hline $\begin{array}{l}\text { 6. Dissemination } \\
\text { other } \\
\text { Conspiracy } \\
\text { Theories }\end{array}$ & .94 & 2.07 & 1.19 & $\begin{array}{l}.20 * \\
{[.09, .31]}\end{array}$ & $\begin{array}{l}.83^{*} \\
{[.79, .86]}\end{array}$ & $\begin{array}{l}.16^{*} \\
{[.04, .27]}\end{array}$ & $\begin{array}{l}.10 \\
{[-.01, .21]}\end{array}$ & $\begin{array}{l}.31 * \\
{[.20, .41]}\end{array}$ & & & \\
\hline
\end{tabular}




\begin{tabular}{|c|c|c|c|c|c|c|c|c|c|c|}
\hline $\begin{array}{l}\text { 7. Reflexive } \\
\text { Open- } \\
\text { Mindedness }\end{array}$ & .91 & 2.45 & 0.94 & $\begin{array}{l}.25^{*} \\
{[.14, .36]}\end{array}$ & $\begin{array}{l}.16^{*} \\
{[.05, .27]}\end{array}$ & $\begin{array}{l}.23 * \\
{[.12, .34]}\end{array}$ & $\begin{array}{l}.05 \\
{[-.06, .17]}\end{array}$ & $\begin{array}{l}.31 * \\
{[.21, .41]}\end{array}$ & $\begin{array}{l}.17 * \\
{[.06, .28]}\end{array}$ & \\
\hline $\begin{array}{l}\text { 8. Political } \\
\text { Ideology }\end{array}$ & - & 3.13 & 1.66 & $\begin{array}{l}.57 * \\
{[.49, .64]}\end{array}$ & $\begin{array}{l}.19 * \\
{[.08, .30]}\end{array}$ & $\begin{array}{l}.55^{*} \\
{[.46, .62]}\end{array}$ & $\begin{array}{l}.37 * \\
{[.26, .46]}\end{array}$ & $\begin{array}{l}.21 * \\
{[.10, .32]}\end{array}$ & $\begin{array}{l}.05 \\
{[-.06, .17]}\end{array}$ & $\begin{array}{l}.13 * \\
{[.02, .24]}\end{array}$ \\
\hline
\end{tabular}

Note. Values in square brackets indicate the $95 \%$ confidence interval for each correlation, * at least $p<.05$ 


\section{Belief in COVID-19 Conspiracy Theories}

We regressed belief in COVID-19 conspiracy theories on national narcissism. As expected, participants high in national narcissism believed more strongly in COVID-19 conspiracy theories, accounting for $22 \%$ of the variance (see Table 3). This relationship remained significant when we adjusted for national identification, belief in conspiracy theories unrelated to COVID-19, and reflexive open-mindedness, suggesting that the relationship between national narcissism and COVID-19 conspiracy theory beliefs was not due to these other factors (see Table 3). When we regressed COVID-19 conspiracy theory beliefs on national narcissism while adjusting for political ideology, the results also remained significant, $\beta=0.23$, $S E=0.06, t(290)=4.17, p<.001, \mathrm{CI}_{95}=[0.12,0.34], R_{\text {change }}^{2}=.04$.

\section{Dissemination of COVID-19 Conspiracy Theories}

We regressed intentions to disseminate COVID-19 conspiracy theories on national narcissism and found that national narcissists were more inclined to share COVID-19 conspiracy theories, accounting for $6 \%$ of the variance. This relationship remained significant when we adjusted for national identification and intentions to share conspiracy theories unrelated to COVID-19, suggesting that this relationship is not confounded by these factors (see Table 4). The relationship also remained significant when we adjusted for political ideology in a separate robustness check, $\beta=0.20 S E=0.07, t(290)=2.94, p=.004, \mathrm{CI}_{95}=[0.07,0.33], R_{\text {change }}=.03 .^{4}$

We also asked participants about which statement (i.e., conspiracy theory) they would be most likely to post about online. A binomial logistic regression found that national narcissism

\footnotetext{
${ }^{4}$ Because the COVID-19 pandemic has been highly polarized in the US, we also explored the moderating role of partisanship and political ideology. None of these interactions were significant (see Supplement). This suggests that national narcissism is associated with the proneness to believe and disseminate COVID-19 conspiracy theories across the political spectrum and party lines
} 
was associated with a greater preference for conspiracy theory related to COVID-19 (coded 1) over conspiracy theories unrelated to COVID-19 (coded 0), $B=0.34, S E=0.13$, Wald $\chi 2(1)=$ $6.51, p=.011, e^{\mathrm{B}}=1.40, \mathrm{CI}_{95}\left(e^{\mathrm{B}}\right)=[1.08,1.82]$.

We then examined our prediction that the positive relationship between national narcissism and dissemination intentions is mediated by greater belief in COVID-19 conspiracy theories using PROCESS macro v.3.5 (Model 4). We found correlational evidence that was consistent with our predicted mediation model. The indirect effect was significant, $\beta=.14$, BootSE $=.08, \mathrm{CI}_{95}=[.08, .21], 5000$ bootstraps (see Figure 1).

\section{Figure 1}

Correlational Mediation Model Predicting Intentions to Disseminate COVID-19 Conspiracy Theories in Study 1 (United States)

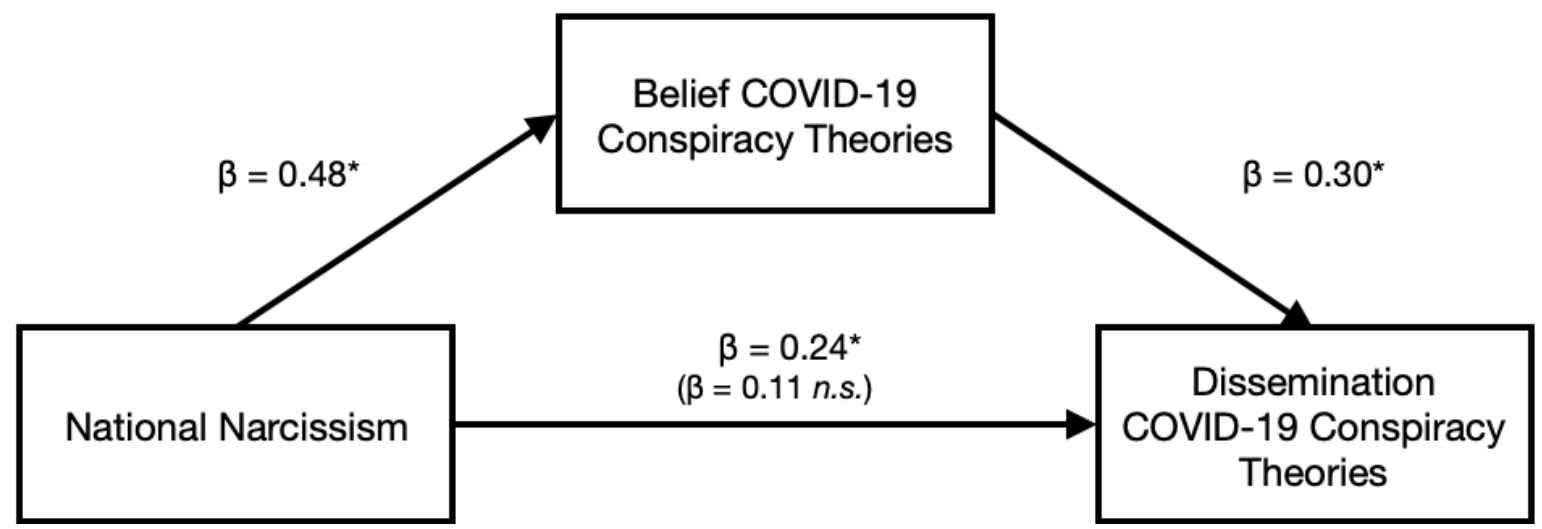

Note. Belief in COVID-19 Conspiracy Theories Mediates the Relationship Between National Narcissism and Intentions to Disseminate COVID-19 Conspiracy Theories in a Correlational Mediation Model. Standardized coefficients are displayed. The direct effect is reported in brackets. * at least $p<.050$

\section{Discussion}

In Study 1, we found correlational evidence that supports our three hypotheses: National narcissism was positively related to belief in COVID-19 conspiracy theories (H1). Further, 
national narcissism was positively associated with intentions to disseminate COVID-19 conspiracy theories (H2) and this relationship was mediated by greater belief in these ideas (H3). Importantly, additional analyses suggested that our results were not confounded by a general tendency to believe and disseminate conspiracy theories, reflexive open-mindedness, national identification, and political ideology.

\section{Study 2 - United Kingdom Survey}

Study 2 replicated and extended the initial findings. Study 1 used two COVID-19 conspiracy theories - one of which was partisan and specific to the US (i.e., COVID-19 was a media scheme to hurt the Trump administration). In Study 2, we refined these measures and removed the media conspiracy theory while also adding six new conspiracy theories to the scales. Further, we tested the possibility that our findings simply reflect a lack of knowledge about COVID-19 and a general tendency to disseminate information related to COVID-19. Since political beliefs are associated with people's conspiracy beliefs (e.g., Nera et al., 2021; van Prooijen et al., 2015), we recruited a more ideological balanced sample than in Study 1. Last, we explored implications of COVID-19 conspiracy theories for attitudes towards public health policies. $^{5}$

\section{Methods}

\section{Participants}

In April 2020, we recruited a sample of 650 UK adult participants on Prolific Academic that was ideologically balanced (approximated by a 50-50 split in participants who voted Leave versus Remain in the Brexit referendum). Participants who did not sign the consent form or

\footnotetext{
${ }^{5}$ We also administered measures of physical hygiene and physical distancing. Due to their low psychometric qualities, we removed these measures. See Supplement and pre-registration notes.
} 
failed the attention check were excluded $\left(\mathrm{N}_{\text {total }}=637 ; 440\right.$ female, 193 male, 4 other; 15 Asian, 11 Black, 589 White, 22 other; $\left.M_{\text {Age }}=37.20, S D_{\text {Age }}=12.40\right)$. Sample size was determined by an a-priori power analysis using $\mathrm{G}^{*}$ Power 3.1 software (Linear multiple regression: Fixed model, $\mathrm{R}^{2}$ increase, Type I error $=.01$, desired Power $\left.=.80\right)$. We chose a conservative effect size of $f^{2}=$ .02 which was much smaller than the effect size observed in Study 1. We considered that (1) Study 2 would be conducted in a different culture (2) circumstances worldwide had changed (e.g., wider spread of the virus) (3) we would perform several robustness checks. Given these parameters, our desired sample size was 588. Anticipating data attrition, we aimed to recruit 650 participants.

\section{Procedure}

Study 2 was conducted online via Qualtrics and approved by the Ethics Board at the [BLINDED]. The study procedure was identical to Study 1.

\section{Measures}

Unless noted otherwise, variables were measured on a 5-point scale with higher numbers reflecting stronger construct manifestations. Descriptive statistics for each measure are reported in Table 2. All key scales are reported in the Supplement.

National Narcissism. We administered a longer, 5-item version of the National Narcissism Scale used in Study 1 to further increase measurement precision (Golec de Zavala et al., 2009).

\section{Belief in and Dissemination Intentions of COVID-19 Conspiracy Theories.} Participants read seven conspiracy theories related to COVID-19 and three facts about the COVID-19 pandemic. Of the seven presented COVID-19 conspiracy theories, five were "deflecting conspiracy theories", claiming that COVID-19 was intentionally created or spread by 
humans (e.g., the pharmaceutical industry expedited the spread of COVID-19 for financial gains) and two were "denial conspiracy theories", claiming that the pandemic was a hoax (e.g., a coverup of $5 \mathrm{G}$ networks). For each statement, participants first rated their agreement $(1=$ not at all to $5=$ very $m u c h)$ and then their intentions to share a post that supported the stated idea $(1=$ not at all to $5=$ very $m u c h)$. Similar to Study 1 , participants also indicated on which social media platform they would share their beliefs for exploratory purposes (see Supplement).

Ratings of agreement and dissemination intention with respect to COVID-19 conspiracy theories formed reliable scales and were averaged to a belief and dissemination intention index, respectively.

Policy Support. We examined participants' support for public policies mitigating the spread of COVID-19. Participants rated their support for four UK public policies combating the COVID-19 pandemic (e.g., closing schools). Responses were averaged.

\section{Covariates.}

National identification was measured with five items based on Cameron (2004), e.g., I feel solidarity with other British people.

\section{Knowledge and Dissemination Intentions of Facts about COVID-19.}

We presented three factual statements about the COVID-19 pandemic alongside the COVID-19 conspiracy theories (e.g., The UK has over 50,000 confirmed COVID-19 cases). Due to the low internal consistency of the agreement ratings $(a=.24)$, items were treated as separate indices for factual knowledge and intentions to disseminate facts related to COVID-19, which constitutes a deviation from the pre-registered analysis plan.

Political Ideology. Participants rated their political ideology from $1=$ Extremely leftwing to $5=$ Extremely right-wing. 


\section{Analyses and Results}

We observed no missing values on any of the independent and dependent variables. We observed no statistical outliers defined as participants whose responses to the predictors/outcomes of interest (national narcissism, COVID-19 conspiracy theory beliefs and dissemination, policy support) exceeded +- 3 Standard Deviations. Zero-order correlations between all measures are reported in Table 2. 


\section{Table 2}

\section{Descriptive Statistics and Correlations of Key Variables in Study 2 (United Kingdom)}

\begin{tabular}{|c|c|c|c|c|c|c|c|c|c|c|c|c|c|c|}
\hline Variable & $\mathrm{a}$ & $M$ & $S D$ & 1 & 2 & 3 & 4 & 5 & 6 & 7 & 8 & 9 & 10 & 11 \\
\hline $\begin{array}{l}\text { 1. Belief COVID-19 } \\
\text { Conspiracy Theories }\end{array}$ & .85 & 1.64 & 0.71 & & & & & & & & & & & \\
\hline $\begin{array}{l}\text { 2. Dissemination } \\
\text { COVID-19 Conspiracy } \\
\text { Theories }\end{array}$ & .90 & 1.31 & 0.62 & $\begin{array}{l}.71 * \\
{[.66, .74]}\end{array}$ & & & & & & & & & & \\
\hline 3. Policy Support & .81 & 4.60 & 0.64 & $\begin{array}{l}-.21 * \\
{[-.28,-.13]}\end{array}$ & $\begin{array}{l}-.18^{*} \\
{[-.26,-.11]}\end{array}$ & & & & & & & & & \\
\hline 4. National Narcissism & .89 & 2.32 & 0.92 & $\begin{array}{l}.31^{*} \\
{[.24, .38]}\end{array}$ & $\begin{array}{l}.26^{*} \\
{[.19, .33]}\end{array}$ & $\begin{array}{l}-.05 \\
{[-.13, .03]}\end{array}$ & & & & & & & & \\
\hline 5. National Identification & .94 & 3.54 & 1.03 & $\begin{array}{l}.12^{*} \\
{[.04, .19]}\end{array}$ & $\begin{array}{l}.08^{*} \\
{[.00, .16]}\end{array}$ & $\begin{array}{l}.03 \\
{[-.05, .11]}\end{array}$ & $\begin{array}{l}.57 * \\
{[.52, .62]}\end{array}$ & & & & & & & \\
\hline 6. Knowledge Fact 1 & - & 2.89 & 1.10 & $\begin{array}{l}.18^{*} \\
{[.10, .25]}\end{array}$ & $\begin{array}{l}.14 * \\
{[.07, .22]}\end{array}$ & $\begin{array}{l}.06 \\
{[-.02, .14]}\end{array}$ & $\begin{array}{l}.06 \\
{[-.02, .13]}\end{array}$ & $\begin{array}{l}-.02 \\
{[-.09, .06]}\end{array}$ & & & & & & \\
\hline 7. Knowledge Fact 2 & - & 3.98 & 1.22 & $\begin{array}{l}.00 \\
{[-.07, .08]}\end{array}$ & $\begin{array}{l}-.01 \\
{[-.09, .07]}\end{array}$ & $\begin{array}{l}.16^{*} \\
{[.08, .24]}\end{array}$ & $\begin{array}{l}.09 * \\
{[.01, .16]}\end{array}$ & $\begin{array}{l}.07 \\
{[-.00, .15]}\end{array}$ & $\begin{array}{l}.05 \\
{[-.03, .13]}\end{array}$ & & & & & \\
\hline 8. Knowledge Fact 3 & - & 2.95 & 1.28 & $\begin{array}{l}.17^{*} \\
{[.10, .25]}\end{array}$ & $\begin{array}{l}.18^{*} \\
{[.11, .26]}\end{array}$ & $\begin{array}{l}.07 \\
{[-.01, .14]}\end{array}$ & $\begin{array}{l}-.07 \\
{[-.15, .01]}\end{array}$ & $\begin{array}{l}-.13 * \\
{[-.20,-.05]}\end{array}$ & $\begin{array}{l}.19^{*} \\
{[.12, .27]}\end{array}$ & $\begin{array}{l}.04 \\
{[-.03, .12]}\end{array}$ & & & & \\
\hline 9. Dissemination Fact 1 & - & 1.75 & 1.07 & $\begin{array}{l}.24 * \\
{[.17, .31]}\end{array}$ & $\begin{array}{l}.41^{*} \\
{[.34, .47]}\end{array}$ & $\begin{array}{l}.01 \\
{[-.07, .08]}\end{array}$ & $\begin{array}{l}.16^{*} \\
{[.08, .24]}\end{array}$ & $\begin{array}{l}.10^{*} \\
{[.02, .17]}\end{array}$ & $\begin{array}{l}.48^{*} \\
{[.42, .54]}\end{array}$ & $\begin{array}{l}.07 \\
{[-.00, .15]}\end{array}$ & $\begin{array}{l}.21^{*} \\
{[.14, .29]}\end{array}$ & & & \\
\hline 10. Dissemination Fact 2 & - & 2.14 & 1.36 & $\begin{array}{l}.18^{*} \\
{[.10, .25]}\end{array}$ & $\begin{array}{l}.34 * \\
{[.27, .41]}\end{array}$ & $\begin{array}{l}.02 \\
{[-.05, .10]}\end{array}$ & $\begin{array}{l}.13^{*} \\
{[.05, .21]}\end{array}$ & $\begin{array}{l}.10^{*} \\
{[.02, .18]}\end{array}$ & $\begin{array}{l}.15^{*} \\
{[.07, .22]}\end{array}$ & $\begin{array}{l}.37^{*} \\
{[.30, .43]}\end{array}$ & $\begin{array}{l}.20^{*} \\
{[.13, .28]}\end{array}$ & $\begin{array}{l}.54^{* *} \\
{[.49, .60]}\end{array}$ & & \\
\hline 11. Dissemination Fact 3 & - & 1.80 & 1.16 & $\begin{array}{l}.29 * \\
{[.21, .36]}\end{array}$ & $\begin{array}{l}.48 * \\
{[.41, .53]}\end{array}$ & $\begin{array}{l}.01 \\
{[-.07, .09]}\end{array}$ & $\begin{array}{l}.11^{*} \\
{[.03, .18]}\end{array}$ & $\begin{array}{l}-.01 \\
{[-.09, .07]}\end{array}$ & $\begin{array}{l}.20^{*} \\
{[.12, .27]}\end{array}$ & $\begin{array}{l}.07 \\
{[-.00, .15]}\end{array}$ & $\begin{array}{l}.52 * \\
{[.46, .57]}\end{array}$ & $\begin{array}{l}.54 * * \\
{[.48, .59]}\end{array}$ & $\begin{array}{l}.51^{* *} \\
{[.45, .56]}\end{array}$ & \\
\hline 12. Political Ideology & - & 2.81 & 0.83 & $\begin{array}{l}.19^{*} \\
{[.11, .26]}\end{array}$ & $\begin{array}{l}.15^{*} \\
{[.07, .22]}\end{array}$ & $\begin{array}{l}-.08 * \\
{[-.16,-.00]}\end{array}$ & $\begin{array}{l}.40^{*} \\
{[.33, .46]}\end{array}$ & $\begin{array}{l}.34 * \\
{[.27, .41]}\end{array}$ & $\begin{array}{l}.02 \\
{[-.06, .09]}\end{array}$ & $\begin{array}{l}.05 \\
{[-.03, .13]}\end{array}$ & $\begin{array}{l}-.10^{*} \\
{[-.18,-.02]}\end{array}$ & $\begin{array}{l}.08 * \\
{[.00, .16]}\end{array}$ & $\begin{array}{l}.04 \\
{[-.04, .12]}\end{array}$ & $\begin{array}{l}-.00 \\
{[-.08, .07]}\end{array}$ \\
\hline
\end{tabular}

Note. Values in square brackets indicate the $95 \%$ confidence interval for each correlation, ${ }^{*} p<.05$ 


\section{Belief in COVID-19 Conspiracy Theories}

Linear regression analysis found that national narcissism was associated with greater belief in COVID-19 conspiracy theories, accounting for $10 \%$ of the variance. This relationship remained significant when we adjusted for national identification and knowledge of the three COVID-19 facts (see Table 3), and also when we adjusted for political ideology in a separate robustness check, $\beta=0.28, S E=0.04, t(634)=6.94, p<.001, \mathrm{CI}_{95}=[0.20,0.37], R_{\text {change }}^{2}=.07$.

\section{Dissemination of COVID-19 Conspiracy Theories}

Linear regression analysis found that national narcissism was positively associated with people's intentions to share COVID-19 conspiracy theories, accounting for $7 \%$ of the variance.

This relationship remained significant when we adjusted for national identification and intentions to share the three facts about COVID-19 (see Table 4), and also when we adjusted for political ideology in a separate robustness check, $\beta=0.24, S E=0.04, t(634)=5.85,24, p<.001$, $\mathrm{CI}_{95}=[0.16,0.32], R_{\text {change }}^{2}=.05 .^{6}$

Similar to Study 1, we used PROCESS macro v.3.5 (Model 4) to gather correlational evidence for our hypothesis that the positive relationship between national narcissism and intentions to disseminate COVID-19 conspiracy theories is mediated by belief in COVID-19 conspiracy theories. Correlational evidence supported our hypothesis, $\beta=.22$, BootSE $=.03$, $\mathrm{CI}_{95}$ $=[.16, .28], 5000$ bootstraps (see Figure 2)

\section{Figure 2}

Correlational Mediation Model Predicting Intentions to Disseminate COVID-19 Conspiracy Theories in Study 2 (United Kingdom)

\footnotetext{
${ }^{6}$ Political ideology and partisanship did not moderate the relationships between national narcissism and people's tendency to believe and disseminate COVID-19 conspiracy theories (see Supplement)
} 


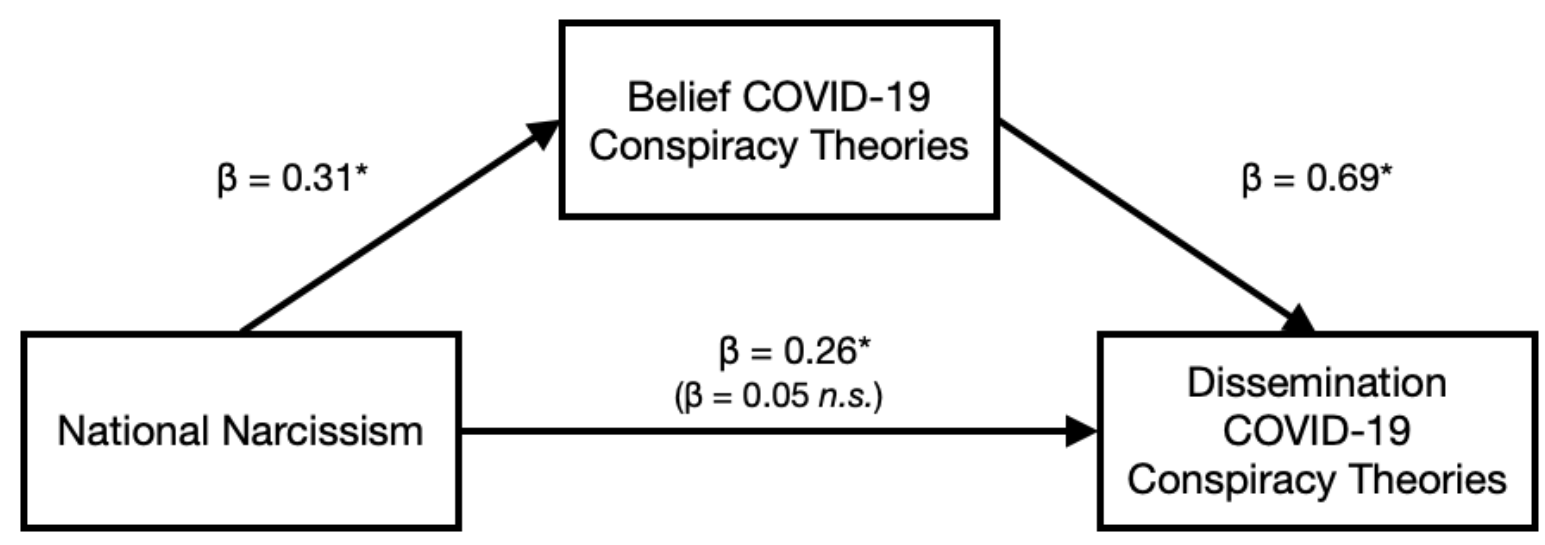

Note. Standardized coefficients are displayed. The direct effect is reported in brackets. ${ }^{*}$ at least $p<.050$

\section{Table 3}

Multiple Linear Regression Analysis of Belief in COVID-19 Conspiracy Theories in Studies 1 (United States) \& 2 (United Kingdom)

\begin{tabular}{|c|c|c|c|c|c|c|c|c|c|c|}
\hline \multirow[b]{2}{*}{ Predictors } & \multicolumn{5}{|c|}{ Study 1 (US) } & \multicolumn{5}{|c|}{ Study 2 (UK) } \\
\hline & $\beta$ & SE & $\mathrm{t}$ & $p$ & $95 \% \mathrm{CI}$ & $\beta$ & $\mathrm{SE}$ & $\mathrm{t}$ & $p$ & $95 \% \mathrm{CI}$ \\
\hline \multicolumn{11}{|l|}{ Main Model } \\
\hline (Intercept) & -0.00 & 0.05 & 6.83 & $<.001$ & $-0.10-0.10$ & -0.00 & 0.04 & 14.96 & $<.001$ & $-0.07-0.07$ \\
\hline National Narcissism & 0.48 & 0.05 & 9.21 & $<.001$ & $0.37-0.58$ & 0.31 & 0.04 & 8.33 & $<.001$ & $0.24-0.39$ \\
\hline
\end{tabular}

Robustness Model

\begin{tabular}{|c|c|c|c|c|c|c|c|c|c|c|}
\hline (Intercept) & -0.00 & 0.04 & -1.65 & .101 & $-0.09-0.09$ & -0.00 & 0.04 & 4.91 & $<.001$ & $-0.07-0.07$ \\
\hline National Narcissism & 0.29 & 0.05 & 5.77 & $<.001$ & $0.19-0.39$ & 0.36 & 0.04 & 7.95 & $<.001$ & $0.27-0.45$ \\
\hline $\begin{array}{l}\text { National } \\
\text { Identification }\end{array}$ & 0.08 & 0.05 & 1.59 & .114 & $-0.02-0.17$ & -0.06 & 0.05 & -1.35 & .177 & $-0.15-0.03$ \\
\hline $\begin{array}{l}\text { Belief other } \\
\text { conspiracy theories }\end{array}$ & 0.50 & 0.05 & 10.57 & $<.001$ & $0.41-0.59$ & & & & & \\
\hline $\begin{array}{l}\text { Reflexive open- } \\
\text { mindedness }\end{array}$ & 0.02 & 0.05 & 0.51 & .608 & $-0.07-0.11$ & & & & & \\
\hline Knowledge Fact 1 & & & & & & 0.13 & 0.04 & 3.34 & .001 & $0.05-0.20$ \\
\hline
\end{tabular}




\begin{tabular}{lllllll} 
Knowledge Fact 2 & & -0.04 & 0.04 & -0.97 & .331 & $-0.11-0.04$ \\
Knowledge Fact 3 & & 0.17 & 0.04 & 4.48 & $<.001$ & $0.09-0.24$ \\
\hline Observations & 293 & 637 & & & \\
$\mathrm{R}^{2} / \mathrm{R}^{2}$ adjusted & $0.46 / 0.45$ & $0.16 / 0.15$ & & \\
\hline
\end{tabular}

Note. National narcissism is a significant, statistical predictor of belief in COVID-19 conspiracy theories even after adjusting for various covariates in Studies $1 \& 2$. Standardized estimates are reported.

\section{Table 4}

Multiple Linear Regression Analysis of Intentions to Disseminate COVID-19 Conspiracy Theories in Studies 1 (United States) \& 2 (United Kingdom)

\begin{tabular}{|c|c|c|c|c|c|c|c|c|c|c|}
\hline \multirow[b]{2}{*}{ Predictors } & \multicolumn{5}{|c|}{ Study 1 (US) } & \multicolumn{5}{|c|}{ Study 2 (UK) } \\
\hline & $\beta$ & SE & $\mathrm{t}$ & $p$ & $95 \% \mathrm{CI}$ & $\beta$ & $\mathrm{SE}$ & $\mathrm{t}$ & $p$ & $95 \% \mathrm{CI}$ \\
\hline \multicolumn{11}{|l|}{ Main Model } \\
\hline (Intercept) & 0.00 & 0.06 & 7.60 & $<.001$ & $-0.11-0.11$ & -0.00 & 0.03 & 6.71 & $<.001$ & $-0.07-0.07$ \\
\hline $\begin{array}{l}\text { National } \\
\text { Narcissism }\end{array}$ & 0.24 & 0.06 & 4.27 & $<.001$ & $0.13-0.35$ & 0.26 & 0.04 & 6.88 & $<.001$ & $0.19-0.34$ \\
\hline \multicolumn{11}{|l|}{ Robustness Model } \\
\hline (Intercept) & 0.00 & 0.03 & -1.87 & .063 & $-0.06-0.06$ & -0.00 & 0.03 & 6.71 & $<.001$ & $-0.07-0.07$ \\
\hline $\begin{array}{l}\text { National } \\
\text { Narcissism }\end{array}$ & 0.10 & 0.04 & 2.87 & .004 & $0.03-0.17$ & 0.24 & 0.04 & 5.76 & $<.001$ & $0.16-0.32$ \\
\hline $\begin{array}{l}\text { National } \\
\text { Identification }\end{array}$ & 0.04 & 0.03 & 1.16 & .248 & $-0.03-0.11$ & -0.08 & 0.04 & -1.87 & .062 & $-0.16-0.00$ \\
\hline $\begin{array}{l}\text { Dissemination other } \\
\text { conspiracy theories }\end{array}$ & 0.81 & 0.03 & 24.87 & $<.001$ & $0.75-0.87$ & & & & & \\
\hline $\begin{array}{l}\text { Dissemination } \\
\text { Fact } 1\end{array}$ & & & & & & 0.17 & 0.04 & 3.87 & $<.001$ & $0.08-0.25$ \\
\hline $\begin{array}{l}\text { Dissemination } \\
\text { Fact } 2\end{array}$ & & & & & & 0.06 & 0.04 & 1.53 & .127 & $-0.02-0.15$ \\
\hline $\begin{array}{l}\text { Dissemination } \\
\text { Fact } 3\end{array}$ & & & & & & 0.33 & 0.04 & 7.91 & $<.001$ & $0.25-0.41$ \\
\hline Observations & 293 & & & & & 637 & & & & \\
\hline $\mathrm{R}^{2} / \mathrm{R}^{2}$ adjusted & 0.702 & 699 & & & & $0.303 /$ & 297 & & & \\
\hline
\end{tabular}

Note. National narcissism is a significant, statistical predictor of intentions to disseminate COVID-19 conspiracy theories even after adjusting for various covariates in Studies $1 \& 2$. Standardized estimates are reported. 


\section{Policy Support}

A linear regression analysis found that greater belief in COVID-19 conspiracy theories was associated with lower policy support, $\beta=-0.21, S E=0.04, t(635)=-5.35, p<.001, \mathrm{CI}_{95}=[-$ $0.28,-0.13]$, adjusted $R^{2}=.04$. We then explored the interrelationships between national narcissism, conspiracy theory belief, and policy support. Research suggests that the overlap between national identification and national narcissism sometimes obscures negative relationships between national narcissism and harmful health behaviors and attitudes (Cislak et al., 2021; Marchlewska et al., 2020, Van Bavel et al., 2021), so we adjusted for national identification. We conducted a multiple linear regression, predicting policy support from national narcissism and national identification using PROCESS for SPSS v3.5 (Model 4). Belief in COVID-19 conspiracy theories mediated a negative relationship between national narcissism and policy support, $\beta=-.08$, BootSE $=.03, \mathrm{CI}_{95}=[-.13,-.03], 5000$ bootstraps.

\section{Discussion}

In Study 2, we successfully replicated and extended the results of Study 1 in a different culture (United Kingdom). We found additional support that national narcissism is positively associated with belief in COVID-19 conspiracy theories (H1) and intentions to disseminate these narratives $(\mathrm{H} 2)$. We also replicated the correlational mediation found in Study 1, suggesting that greater belief in COVID-19 conspiracy theories mediates the relationship between national narcissism and intentions to disseminate COVID-19 conspiracy theories. Additionally, we found evidence that lack of knowledge about the pandemic and proneness to post about COVID-19, national identification, and political ideology did not account for these findings. Last, our exploratory analyses found that belief in COVID-19 conspiracy theories mediates a negative 
relationship between national narcissism and support for public policies aimed at mitigating the spread of COVID-19.

\section{Study 3 - International Survey}

National narcissism was positively related to the readiness to believe and disseminate COVID-19 conspiracy theories in the first two studies. However, both studies were conducted in Western, industrialized, and Democratic countries, which constitute less than $15 \%$ of the global population (Henrich et al., 2010, Nielsen et al., 2017). Further, in both studies, one conspiracy theory implicated China - a country that some people in the US and the UK construe as a national rival. To examine the possibility that our findings are idiosyncratic to Western societies or a mere manifestation of biases against China, we analyzed cross-cultural data from large international dataset (Van Bavel, Cichocka et al., 2021)7.

\section{Methods}

\section{Participants}

The dataset comprised 51,089 participants recruited from 67 countries between April and May 2020. As pre-registered, we excluded countries with less than 90 observations from our analyses. The final sample included 50,757 participants $\left(M_{\mathrm{Age}}=42,95 S D_{\mathrm{Age}}=16.06\right)$ from 56 countries, sufficiently big sample sizes to provide unbiased estimates of regression coefficients, variance components, and standard errors (Maas \& Hox, 2005) and over 95\% statistical power to detect a fixed effect of medium size $(\delta=.50, \mathrm{ICC}=.20, \mathrm{a}=.05$; Scherbaum \& Pesner, 2019). A list of all countries represented is reported in Supplement. Conclusions did not change when we analyzed all 67 countries.

\footnotetext{
${ }^{7}$ Data was prepared and shared by Azevedo et al. (2021) and will be available upon publication of the original paper (https://osf.io/tfsza)
} 


\section{Procedure}

Data was collected by national research teams who administered the survey online or in paper-pencil format in their local communities. The original, English-language survey was translated into local languages using forward-backward translation. The study was approved by the Ethics Committee at [BLINDED].

\section{Measures}

The dataset comprises a series of measures. For this study, we analyzed national narcissism, belief in COVID-19 conspiracy theories, and behaviors and attitudes related to COVID-19 health measures (physical distancing, physical hygiene, policy support). The dataset also includes measures of national identification, individual narcissism, and reflection which we probed as potential confounds. The authors did not measure intentions to disseminate COVID-19 conspiracy theories. Unless noted otherwise, variables were measured on an 11-point scale $(0=$ strongly disagree, $5=$ neither agree nor disagree, $10=$ strongly agree). Descriptive statistics for each measure are reported in Table 5.

National Narcissism. National Narcissism was measured with the three-item scale that we used in Study 1 (Golec de Zavala et al., 2009).

Belief in COVID-19 Conspiracy Theories. The authors measured belief in COVID-19 conspiracy theories similar to our Studies $1 \& 2$. Participants were presented with four conspiracy theories about the COVID-19 pandemic and asked how much they agreed with each of them. Responses were averaged. These conspiracy theories did not implicate particular national groups.

National Identification. National identification was measured as the average of two items (e.g., I identify as [nationality]). 
Individual Narcissism. Individual narcissism was measured with a six-item scale (Back et al., 2013; e.g., I react annoyed if another person steals the show from me.)

Reflection. Participants solved three problems which had an intuitive yet incorrect answer (Primi et al., 2016). The task measures how careful and reflective participants evaluate information. ${ }^{8}$ We coded incorrect answers as 0 and correct answers as 3.66 . We chose this coding scheme to make the variance of the reflection measure approximately similar to the other independent variables which are measured on a scale from 0 to 10 . On average, participants solved 1.35 problems.

Health Behaviors and Policy Support. Health behaviors and attitudes towards public policies were measured each with five items on an 11-point scale in increments of ten $(0=$ strongly disagree, $50=$ neither agree nor disagree, $100=$ strongly agree $)$.

Physical Distancing. Participants reported to what extent they engaged in each of the five presented physical distancing behaviors (e.g., During the days of the coronavirus [COVID-19] pandemic, I have been staying at home as much as practically possible.) As recommended by the original authors, item 2 was removed from the scale to increase reliability. We averaged the remaining four items.

Physical Hygiene. Participants reported how much they increased each of the five presented physical hygiene behaviors during the pandemic (e.g., During the days of the coronavirus [COVID-19] pandemic, I have been washing my hands longer than usual.) Responses were averaged.

\footnotetext{
8 There is a debate in the literature on what construct(s) such tests capture (e.g., analytical processing, numeracy, executive control, disposition to be careful and reflective; See, Lawson et al., 2020 and Szaszi et al., 2017).
} 
Policy Support. Participants reported how favorable they felt towards five public policies combating the COVID-19 pandemic (e.g., During the days of the coronavirus [COVID19] pandemic, I have been in favor of forbidding all non-necessary travel.)

\section{Analyses and Results}

For each analysis, we excluded participants with missing values on any of the variables. Since subjects are nested within countries, we used multilevel modelling. We used random effect models that allow for distinct within and between effects to analyze the data ("REWB", Bell et al., 2019). For each model, we modelled the intercept as random and the focal predictor as fixed effect and random effect. We group-mean-centered all predictors within countries so that each individual score reflects the construct manifestation in relation to other participants from the same country. For each hypothesis, we examined the focal predictor's fixed effect to test our hypothesis. Parameters were estimated using the Restricted Maximum Likelihood Methods (REML). ${ }^{9}$ For our main hypothesis and research questions, we did not observe more than $15 \%$ influential data and proceeded with the pre-registered analysis plan. Zero-order correlations between all variables are reported in Table 6. Interactive data visualization is available on https://rpubs.com/AnniSternisko/.

\footnotetext{
${ }^{9}$ The calculation of $p$ values and confidence intervals for linear mixed models is complex and often imprecise. Values should be interpreted with caution (Maas \& Hox, 2005)
} 


\section{Table 5}

Descriptive Statistics and Correlations of Key Variables in International Study 3

\begin{tabular}{|c|c|c|c|c|c|c|c|c|c|c|c|}
\hline Variable & $a$ & $M$ & $S D$ & 1 & 2 & 3 & 4 & 5 & 6 & 7 & 8 \\
\hline $\begin{array}{l}\text { 1. Belief } \\
\text { COVID-19 } \\
\text { Conspiracy } \\
\text { Theories }\end{array}$ & .92 & 3.14 & 2.95 & & & & & & & & \\
\hline $\begin{array}{l}\text { 2. National } \\
\text { Narcissism }\end{array}$ & .87 & 4.94 & 2.82 & $\begin{array}{c}.38^{*} \\
{[.37, .39]}\end{array}$ & & & & & & & \\
\hline $\begin{array}{l}\text { 3. Policy } \\
\text { Support }\end{array}$ & .87 & 7.86 & 2.27 & $\begin{array}{c}-.12 * \\
{[-.13,-.11]}\end{array}$ & $\begin{array}{c}.14 * \\
{[.13, .15]}\end{array}$ & & & & & & \\
\hline $\begin{array}{l}\text { 4. Physical } \\
\text { Hygiene }\end{array}$ & .79 & 7.93 & 1.89 & $\begin{array}{c}-.03 * \\
{[-.04,-.02]}\end{array}$ & $\begin{array}{c}.15^{*} \\
{[.15, .16]}\end{array}$ & $\begin{array}{c}.43 * \\
{[.42, .43]}\end{array}$ & & & & & \\
\hline $\begin{array}{l}\text { 5. Physical } \\
\text { Distancing }\end{array}$ & .78 & 8.50 & 1.77 & $\begin{array}{c}-.16^{*} \\
{[-.17,-.15]}\end{array}$ & $\begin{array}{c}.02 * \\
{[.01, .03]}\end{array}$ & $\begin{array}{c}.46^{*} \\
{[.46, .47]}\end{array}$ & $\begin{array}{c}.45^{*} \\
{[.44, .46]}\end{array}$ & & & & \\
\hline $\begin{array}{l}\text { 6. National } \\
\text { Identification }\end{array}$ & $\begin{array}{l}r= \\
.68\end{array}$ & 7.80 & 2.53 & $\begin{array}{c}.12^{*} \\
{[.11, .13]}\end{array}$ & $\begin{array}{c}.44 * \\
{[.43, .45]}\end{array}$ & $\begin{array}{c}.15^{*} \\
{[.14, .16]}\end{array}$ & $\begin{array}{c}.19^{*} \\
{[.18, .20]}\end{array}$ & $\begin{array}{c}.13 * \\
{[.12, .14]}\end{array}$ & & & \\
\hline $\begin{array}{l}\text { 7. Individual } \\
\text { Narcissism }\end{array}$ & .79 & 4.20 & 2.01 & $\begin{array}{c}.27^{*} \\
{[.26, .28]}\end{array}$ & $\begin{array}{c}.30 * \\
{[.30, .31]}\end{array}$ & $\begin{array}{c}-.01 \\
{[-.02, .00]}\end{array}$ & $\begin{array}{c}.01 * \\
{[.00, .02]}\end{array}$ & $\begin{array}{c}-.07 * \\
{[-.08,-.07]}\end{array}$ & $\begin{array}{c}.07 * \\
{[.07, .08]}\end{array}$ & & \\
\hline 8. Reflection & - & 1.35 & 1.35 & $\begin{array}{c}-.26^{*} \\
{[-.27,-.26]}\end{array}$ & $\begin{array}{c}-.26^{*} \\
{[-.26,-.25]}\end{array}$ & $\begin{array}{c}-.07 * \\
{[-.08,-.06]}\end{array}$ & $\begin{array}{c}-.10^{*} \\
{[-.11,-.10]}\end{array}$ & $\begin{array}{c}.02 * \\
{[.01, .03]}\end{array}$ & $\begin{array}{c}-.12^{*} \\
{[-.13,-.12]}\end{array}$ & $\begin{array}{c}-.08 * \\
{[-.09,-.07]}\end{array}$ & \\
\hline
\end{tabular}


NATIONAL NARCISSISM AND COVID-19 CONSPIRACY THEORIES

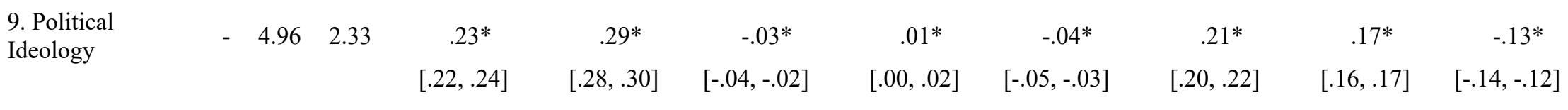




\section{Belief in Conspiracy Theories}

First, we fitted a multilevel model that regressed belief in COVID-19 conspiracy theories on national narcissism. As predicted, the fixed effect of national narcissism was positive and significant. On average, national narcissists reported stronger belief in COVID-19 conspiracy theories (see Table 6). When we added national identification, individual narcissism, and cognitive reflection as fixed effects into the model, the fixed effect of national narcissism remained positive and significant, suggesting that general ingroup positivity, narcissistic tendencies, and low reflection cannot fully account for our finding (see Table 6). ${ }^{10}$ The relationship also remained significant when we adjusted for political ideology, $B=0.27, S E=$ $0.02, p<.001, \mathrm{CI}_{95}=[0.23,0.31], \mathrm{ICC}=.20$, marginal $R^{2}=.08^{11}$.

\section{Table 6}

Mixed Model Analysis Predicting Belief in COVID-19 Conspiracy Theories Across 56 Countries

\section{Main Model}

\begin{tabular}{lcccccc} 
Predictors & $\mathrm{B}$ & $95 \% \mathrm{CI}$ & $p$ & $\mathrm{~B}$ & $95 \% \mathrm{CI}$ & $p$ \\
\hline (Intercept) & 3.20 & {$[2.88-3.51]$} & $<.001$ & 3.18 & {$[2.86-3.49]$} & $<.001$ \\
National Narcissism & 0.29 & {$[0.25-0.34]$} & $<.001$ & 0.24 & {$[0.20-0.28]$} & $<.001$ \\
National Identification & & & & -0.07 & {$[-0.08--0.06]$} & $<.001$ \\
Individual Narcissism & & & 0.23 & {$[0.22-0.24]$} & $<.001$ \\
Reflection & & & -0.33 & {$[-0.35--0.31]$} & $<.001$
\end{tabular}

\footnotetext{
${ }^{10}$ For more detail see Supplement Tables $3.1 \& 3.2$.

11 The interaction between political ideology and national narcissism was significant, yet very weak. National narcissism was positively related to the belief in COVID-19 conspiracy theories amongst both liberals and conservatives (see Supplement)
} 


\begin{tabular}{lll}
$\begin{array}{ll}\text { Random Effects } \\
\sigma^{2}\end{array}$ & 6.44 & 6.01 \\
$\tau_{00}$ & 1.44 Country & $1.46_{\text {Country (random intercept country) }}$ \\
$\tau_{11}$ & 0.03 Country.NationalNarcissism & 0.02 Country.NationalNarcissism \\
$\rho_{01}$ & -0.04 Country & -0.11 Country (rand eff corr) \\
$\mathrm{ICC}$ & 0.20 & 0.21 \\
$\mathrm{~N}$ & 56 Country & 56 Country \\
\hline Observations & 48029 & 45558 \\
$\mathrm{R}^{2}$ & $.06 / .25$ & $.10 / .29$ \\
\hline
\end{tabular}

Note. All predictors were group-mean-centered. $\sigma^{2}$ denotes within-country variance, $\tau_{00}$ denotes acrosscountry variance, $\tau_{11}$ denotes variance of national narcissism coefficient across countries, ICC denotes Intraclass Correlation Coefficient.

\section{Health Behaviors and Policy Support}

We fitted three multilevel models in which we specified belief in COVID-19 conspiracy theories as the statistical predictor and [a] physical hygiene $[\mathrm{b}]$ physical distancing $[\mathrm{c}]$ policy support as the outcomes, respectively. In all models, the fixed effect of belief in COVID-19 conspiracy theories was significant and negative. On average, stronger belief in COVID-19 conspiracy theories was associated with less physical hygiene (albeit weakly), less physical distancing, and less support for public policies that mitigate the COVID-19 pandemic. These relationships showed little variance between countries (see Table 7).

\section{Table 7}

Mixed Model Analysis Predicting Health Behaviors and Attitudes Across 56 Countries

Physical Hygiene

Predictors

B $\quad 95 \% \mathrm{CI}$

$p \quad$ B $\quad 95 \% \mathrm{CI}$

Physical Distancing

Policy Support

$95 \% \mathrm{CI}$

$p$

B
$95 \% \mathrm{CI}$ $p$ 


\begin{tabular}{|c|c|c|c|c|c|c|c|c|c|}
\hline (Intercept) & 8.04 & $7.84-8.20$ & $<.001$ & 8.55 & $8.42-8.67$ & $<.001$ & 8.07 & $7.83-8.31$ & $<.001$ \\
\hline $\begin{array}{l}\text { Belief in } \\
\text { COVID-19 } \\
\text { Conspiracy } \\
\text { Theories }\end{array}$ & -0.04 & $-0.05--0.02$ & $<.001$ & -0.09 & $-0.10--0.07$ & $<.001$ & -0.12 & $-0.15--0.10$ & $<.001$ \\
\hline \multicolumn{10}{|c|}{ Random Effects } \\
\hline$\sigma^{2}$ & 3.20 & & & 2.83 & & & 4.13 & & \\
\hline$\tau_{00}$ & 0.37 Coun & & & 0.23 Country & & & 0.84 Country & & \\
\hline$\tau_{11}$ & 0.00 Coun & ry.ConspiracyBelief & & 0.00 Country & y. ConspiracyBelief & & 0.01 Country. & y. ConspiracyBelief & \\
\hline$\rho_{01}$ & 0.25 Coun & & & 0.48 Country & & & 0.16 Country & & \\
\hline ICC & 0.11 & & & 0.08 & & & 0.18 & & \\
\hline $\mathrm{N}$ & 56 Country & & & 56 Country & & & 56 Country & & \\
\hline Observations & 48140 & & & 48148 & & & 48142 & & \\
\hline $\begin{array}{l}\text { Marginal } \mathrm{R}^{2} / \\
\text { Conditional } \\
\mathrm{R}^{2}\end{array}$ & $.003 / .1$ & & & $.02 / .10$ & & & $.02 / .20$ & & \\
\hline
\end{tabular}

Note. All predictors were group-mean-centered. $\sigma^{2}$ denotes within-country variance, $\tau_{00}$ denotes across-country variance, $\tau_{11}$ denotes variance of belief in COVID-19 conspiracy theories coefficient across countries, ICC denotes Intraclass Correlation Coefficient.

We then explored the interrelationships between national narcissism, COVID-19 conspiracy theory beliefs, and health behaviors and policy support. Using the R package "Imer", we fitted three multilevel models predicting [1] physical hygiene, [2] physical distancing and [3] policy support from national narcissism (modeled as fixed and random effect), adjusting for national identification (modeled as fixed effect). Intercepts were modelled as random. We found positive, yet weak, fixed effects of national narcissism on physical hygiene, $B=0.06, p<.001$, $\mathrm{CI}_{95 \%}=[0.04,0.08], p<.001$, and (marginally significant) on policy support, $B=0.02, \mathrm{CI}_{95 \%}=[-$ $0.00,0.05], p=.071$. The fixed effect of national narcissism was not significant for physical distancing, $B=-0.01, p=.162, \mathrm{CI}_{95}=[-0.04,0.01]$. We used the R package "mediate" to examine the mediating role of belief in COVID-19 conspiracy theories. Across all outcome 
variables, we found significant, negative indirect effects $\left(B_{\text {Hygiene }}=-0.03, p<.001 ; B_{\text {Distancing }}=\right.$ $\left.0.04, p<.001 ; B_{\text {Policy }}=-0.06, p<.001\right)$ and positive, yet weak, direct effects $\left(B_{\text {Hygiene }}=0.08, p\right.$ $\left.<.001, B_{\text {Distancing }}=0.02, p=.088 ; B_{\text {Policy }}=0.08, p<.001\right)$. Together, these results suggest that belief in COVID-19 conspiracy theories mediates negative relationships between national narcissism and health behaviors and policy support. However, there also seems to be other psychological processes at play which link national narcissism to greater engagement in health behavior and greater support for public health policies.

\section{General Discussion}

In three studies, with data from 51,707 participants from 56 countries, we examined the relationships between national narcissism, COVID-19 conspiracy theories, and health behaviors and policy attitudes. Across culturally diverse samples, we found that greater national narcissism was associated with stronger belief in COVID-19 conspiracy theories (Studies 1-3). In the US and the UK, national narcissism was also positively related to intentions to disseminate COVID19 conspiracy theories (Studies $1 \& 2$ ). This relationship was mediated by greater belief in COVID-19 conspiracy theories (Studies $1 \& 2$ ). These relationships were very robust ${ }^{12}$ and persisted when we adjusted for a series of relevant covariates. National narcissism might be an important risk factor for the spread of conspiracy theories during the pandemic.

We found correlational evidence suggesting that belief in COVID-19 conspiracy theories may have serious consequences for the global containment of the pandemic. Across 56 countries, belief in COVID-19 conspiracy beliefs were related to less adherence to public health guidelines (i.e., physical hygiene, physical distancing; Study 3) and less support for public health policies

\footnotetext{
12 They have also already been subject to a successful conceptual replication by Hughes and Machan (2020)
} 
(Studies $2 \& 3$ ). These effects were generally small which may partly be due to restricted variance. People reported high engagement in health behavior and policy support but low belief in COVID-19 conspiracy theories. Given the globality and contagiousness of the virus, however, even subtle negligence can be detrimental. We also found that COVID-19 conspiracy theory beliefs mediated a negative relationship between national narcissism and engagement in health behaviors (Study 3) and policy support (Studies $2 \& 3$ ).

\section{Theoretical Contributions and Implications}

Our study expands previous work on conspiracy theories and public health by examining the role of social identity processes. We found that national narcissism - a defensive belief in the greatness of one's nation that requires external recognition - was positively related to the readiness to believe and disseminate COVID-19 conspiracy theories. Critically, neither general ingroup positivity (Studies 1-3) nor individual narcissism (Study 3) could fully account for our findings. It was the defensive love for the nation - captured in national narcissism - that seemed to be crucial.

Further, the relationship between national narcissism and belief in COVID-19 conspiracy theories persisted when adjusting for participants' belief in conspiracy theories unrelated to COVID-19 (Study 1), suggesting that national narcissists are not drawn to simply any kind of conspiracy theories (see Bertin et al., 2021; Cichocka, Marchlewska, \& Golec de Zavala, 2016). In fact, national narcissism was unrelated to belief in conspiracy theories about topics like politics (e.g., 9/11 inside job) and other public health issues (e.g., HIV, vaccines). This suggests that at the time of data collection COVID-19 conspiracy theories corresponded to a specific social identity need (Enders \& Uscinski, 2021; Sternisko et al., 2020), presumably the desire to deny or deflect national shortcomings exposed by the pandemic. 
Even though belief in COVID-19 conspiracy theories and national narcissism were associated with reflexive open-mindedness (Study 1) and low reflection (Study 3), the association between national narcissism and belief in COVID-19 conspiracy theories remained significant when we adjusted for these factors, as well as factual knowledge about COVID-19 (Study 2). These findings highlight that conspiracy theory beliefs amongst national narcissists are not simply a product of limited cognitive effort and gullibility (Van Bavel \& Perreira, 2018; Zmigrod et al., 2018). Certain strategies to reduce the spread of misinformation like accuracy nudges (Pennycook et al., 2020) and media education (Basol et al., 2020) may therefore prove less effective for national narcissists.

Further, we found that the relationship between national narcissism and conspiracy theory beliefs occurs outside the context of intergroup conflict. We found that national narcissists latched onto conspiracy theories specifically related to COVID-19, regardless of who is the alleged conspirator. This suggests that conspiracy theories are a generalized maladaptive ingroup defense strategy amongst national narcissists (Cislak et al., 2021; Marchlewska et al., 2019).

Little research has examined the psychological risk factors for the spread of conspiracy theories. We found that national narcissism may be a risk factor for the dissemination of conspiracy theories (Hughes \& Machan, 2020). At first, our findings may seem obvious: people with stronger conspiracy theory beliefs - people high in national narcissism - should also be more likely to disseminate them. However, the formation and dissemination of people's public beliefs are much more complex (León-Medina et al., 2020). For instance, people anticipate negative judgment and social exclusion for publicly supporting conspiracy theories (Lantian et al., 2018). In such situations, private and public opinions often become misaligned (LeónMedina et al., 2020). Our findings hint at an interesting psychological phenomenon worth future 
investigation: national narcissists may be more willing than others to imperil their personal image in the interest of defending their ingroup's image.

Exploratory analyses found evidence that national narcissists' stronger belief in COVID19 conspiracy theories is linked to less engagement in health behaviors and less support for policies mitigating the COVID-19 pandemic. However, looking at the total and direct effects of national narcissism a more complicated picture emerged. In Study 2, national narcissism was negatively related to policy support after adjusting for national identification. However, national narcissism was positively albeit weakly, related to policy support and physical hygiene and was not related to physical distancing in Study 3 (Van Bavel, Cichocka et al., 2021). When we accounted for conspiracy theories in our mediation models, the direct relationships remained positive, yet weak. These findings suggest that while national narcissism might be associated with lower willingness to adhere to pandemic related guidelines via conspiracy beliefs, other psychological processes might be operating in parallel motivating national narcissists to support policies and regulations to the extent they view them as beneficial to maintaining the positive ingroup image (Cislak et al., 2021, Grondfeldt et al., 2021). More research is needed to unpack these relationships.

\section{Limitations and Future Directions}

We found that the relationship between national narcissism and belief in COVID-19 conspiracy theories was relatively robust across contexts. Nevertheless, some countries deviated from general trends, suggesting that our findings are not universally true. Further, participants from Africa and the Middle East were still underrepresented in our studies. In addition, we only measured dissemination intentions in Studies $1 \& 2$, both of which were conducted in W.E.I.R.D countries. This limits the generalizability of the corresponding findings. We encourage research 
to replicate our findings with these populations and also explore potential moderators (see Supplement on gender and ethnicity). We also highlight that all measures relied on self-report and slightly varied across studies. Despite these variations in measurements, our results were consistent across studies which lends further confidence in our conclusions. Last, we note that beliefs in conspiracy theories were quite low. As such, our work is best understood as examining the underlying motives of those who depart from a norm of skepticism towards conspiracy theories.

Since national narcissism is relatively stable over time (Cichocka et al., 2018), we suspect that national narcissism motivates the belief in and dissemination of COVID-19 conspiracy theories which translates into adverse health behaviors and attitudes rather than the reverse. However, our data is cross-sectional. More work is needed to justify this interpretation. If future research finds evidence that national narcissism increases people's proneness to believe and disseminate COVID-19 conspiracy theories, practical implications are worthwhile exploring. For instance, underscoring that the national in-group is disadvantaged in fighting the pandemic might heighten the need to assert the image of the group and further fuel conspiracy theories (Marchlewska et al., 2018). Conversely, public-health messages might benefit from stressing that the adherence to health guidelines such as getting the COVID-19 vaccine helps protect the nation's image.

\section{Conclusion}

National narcissism appeared as a risk factor for COVID-19 conspiracy theories across a variety of contexts with implications for people's health behavior and policy attitudes. Looking at the bigger picture, these findings suggest that some social identity processes related to conspiracy theories are relatively universal. Understanding the role of social identity in 
NATIONAL NARCISSISM AND COVID-19 CONSPIRACY THEORIES

conspiracy theories may thus not only help limit the current 'COVID-19 infodemic' but future ones. 


\section{References}

Ardag, M. M. (2019, December 2). 3-item version of Collective Narcissism Scale. Collective Narcissism. https://collectivenarcissism.com/blog/3item_cns.

Azevedo, F., Pavlovic, T., Rêgo, G. G., Sampaio, W., Van Bavel, J. J., Cichocka, A., Capraro, V., Sjåstad, H., Nezlek, J. B., Alfano, M., ... Sampaio, W. (2021, June 1). Social and Moral Psychology of COVID-19 across 67 Countries. https://osf.io/tfsza

Back, M. D., Küfner, A. C. P., Dufner, M., Gerlach, T. M., Rauthmann, J. F., \& Denissen, J. J. A. (2013). Narcissistic admiration and rivalry: Disentangling the bright and dark sides of narcissism. Journal of Personality and Social Psychology, 105(6), 10131037. https://doi.org/10.1037/a0034431

Basol, M., Roozenbeek, J., \& van der Linden, S. (2020). Good news about bad news: Gamified inoculation boosts confidence and cognitive immunity against fake news. Journal of Cognition, 3(1). https://doi.org/10.5334/joc.91

Bell, A., Fairbrother, M., \& Jones, K. (2018). Fixed and random effects models: making an informed choice. Quality \& Quantity, 53(2), 1051-1074. https://doi.org/10.1007/s11135$\underline{018-0802-\mathrm{X}}$

Bertin, P., Nera, K., Hamer, K., Uhl-Haedicke, I., \& Delouvée, S. (2021, January 13). Stand out of my Sunlight: The Mediating Role of Climate Change Conspiracy Beliefs in the Relationship between National Collective Narcissism and Acceptance of Climate Science. https://doi.org/10.31234/osf.io/cnmfa 
Biddlestone, M., Cichocka, A., Žeželj, I., \& Bilewicz, M. (2020). Conspiracy Theories and Intergroup Relations. Routledge Handbook of Conspiracy Theories, 219-230. https://doi.org/10.4324/9780429452734-2_6

Biddlestone, M., Green, R., \& Douglas, K. M. (2020). Cultural orientation, power, belief in conspiracy theories, and intentions to reduce the spread of COVID-19. British Journal of Social Psychology, 59(3), 663-673. https://doi.org/10.1111/bjso.12397

Cameron, J. E. (2004). A Three-Factor Model of Social Identity. Self and Identity, 3(3), 239262. https://doi.org/10.1080/13576500444000047

Carney, D. R., Jost, J. T., Gosling, S. D., \& Potter, J. (2008). The secret lives of liberals and conservatives: Personality profiles, interaction styles, and the things they leave behind. Political Psychology, 29(6), 807-840. https://doi.org/10.1111/j.1467$\underline{9221.2008 .00668 . x}$

Cichocka, A. (2020, November 10). To counter conspiracy theories, boost well-being. Nature World View. https://www.nature.com/articles/d41586-020-03130-6

Cichocka, A. (2016). Understanding defensive and secure in-group positivity: The role of collective narcissism. European Review of Social Psychology, 27(1), 283-317. https://doi.org/10.1080/10463283.2016.1252530

Cichocka, A., \& Cislak, A. (2020). Nationalism as collective narcissism. Current Opinion in Behavioural Sciences, 34, 69-74. https://doi.org/10.1016/j.cobeha.2019.12.013

Cichocka, A., Golec de Zavala, A., Marchlewska, M., Bilewicz, M., Jaworska, M., \& Olechowski, M. (2018). Personal control decreases narcissistic but increases nonnarcissistic in-group positivity. Journal of Personality, 86(3), 465-480. 
Cichocka, A., Marchlewska, M., \& Golec de Zavala, A. (2016). Does self-love or self-hate predict conspiracy beliefs? Narcissism, self-esteem and the endorsement of conspiracy theories. Social Psychological and Personality Science, 7(2), 157-166. https://doi.org/10.1177/1948550615616170

Cichocka, A., Marchlewska, M., Golec de Zavala, A., \& Olechowski, M. (2016). 'They will not control us': Ingroup positivity and belief in intergroup conspiracies. British Journal of Psychology, 107(3), 556-576. https://doi.org/10.1111/bjop.12158

Cislak, A., Marchlewska, M., Wojcik, A., Sliwiński, K., Molenda, Z., Szczepańska, D., \& Cichocka, A. (2021). National narcissism and support for voluntary vaccination policy: The mediating role of vaccination conspiracy beliefs. Group Processes and Intergroup Relations.

Cislak, A., Wojcik, A. D., \& Cichocka, A. (2018). Cutting the forest down to save your face: Narcissistic national identification predicts support for anti-conservation policies. Journal of Environmental Psychology, 59, 65-73. https://doi.org/10.1016/j.jenvp.2018.08.009

Douglas, K. M. (2021). COVID-19 conspiracy theories. Group Processes \& Intergroup Relations, 24(2), 270-275. https://doi.org/10.1177/1368430220982068

Douglas, K. M., Sutton, R. M., Callan, M. J., Dawtry, R. J., \& Harvey, A. J. (2016). Someone is pulling the strings: Hypersensitive agency detection and belief in conspiracy theories. Thinking \& Reasoning, 22(1), 57-77. https://doi.org/10.1080/13546783.2015.1051586

Douglas, K., Sutton, R., \& Cichocka, A. (2017). The psychology of conspiracy theories. Current Directions in Psychological Science, 26(6), 538-542. https://doi.org/10.1177/0963721417718261 
Douglas, K. M., Uscinski, J. E., Sutton, R. M., Cichocka, A., Nefes, T., Ang, C. S., \& Deravi, F. (2019). Understanding conspiracy theories. Political Psychology, 40, 3-35. https://doi.org/10.1111/pops.12568

Effron, D. A. (2018). It Could Have Been True: How Counterfactual Thoughts Reduce Condemnation of Falsehoods and Increase Political Polarization. Personality and Social Psychology Bulletin, 44(5), 729-745. https://doi.org/10.1177/0146167217746152

Einstein, K. L., \& Glick, D. M. (2015). Do I think BLS data are BS? The consequences of conspiracy theories. Political Behavior, 37(3), 679-701. https://doi.org/10.1007/s11109$\underline{014-9287-Z}$

Enders, A. M., \& Uscinski, J. E. (2021). Are misinformation, antiscientific claims, and conspiracy theories for political extremists?. Group Processes \& Intergroup Relations, 24(4), 583-605. https://doi.org/10.1177/1368430220960805

Federico, C. M., \& De Zavala, A. G. (2018). Collective narcissism and the 2016 US presidential vote. Public Opinion Quarterly, 82(1), 110-121. https://doi.org/10.1093/poq/nfx048

Golec de Zavala, A., \& Cichocka, A. (2012). Collective narcissism and anti-Semitism in Poland. Group Processes \& Intergroup Relations, 15(2), 213-229. https://doi.org/10.1177/1368430211420891

Golec de Zavala, A., Cichocka, A., \& Bilewicz, M. (2013). The Paradox of In-Group Love: Differentiating Collective Narcissism Advances Understanding of the Relationship Between In-Group and Out-Group Attitudes. Journal of Personality, 81(1), 16-28. https://doi.org/10.1111/j.1467-6494.2012.00779.x 
Golec de Zavala, A., Cichocka, A., \& Iskra-Golec, I. (2013). Collective narcissism moderates the effect of in-group image threat on intergroup hostility. Journal of Personality and Social Psychology, 104(6), 1019-1039. https://doi.org/10.1037/a0032215

Golec de Zavala, A., Cichocka, A., Eidelson, R., \& Jayawickreme, N. (2009). Collective narcissism and its social consequences. Journal of Personality and Social Psychology, 97(6), 1074-1096. https://doi.org/10.1037/a0016904

Golec de Zavala, A., Dyduch-Hazar, K., \& Lantos, D. (2019). Collective Narcissism: Political Consequences of Investing Self-Worth in the Ingroup's Image. Political Psychology, 40, 37-74. https://doi.org/10.1111/pops.12569

Golec de Zavala, A., Peker, M., Guerra, R., \& Baran, T. (2016). Collective Narcissism Predicts Hypersensitivity to In-group Insult and Direct and Indirect Retaliatory Intergroup Hostility. European Journal of Personality, 30(6), 532-551. https://doi.org/10.1002/per.2067

Gronfeldt, B., Cichocka, A., Cislak, A., Sternisko, A., \& I. (2021, June 28). A Small Price to Pay: National Narcissism Predicts Readiness to Sacrifice In-group Members to Defend the In-group's Image. https://doi.org/10.31234/osf.io/7fmrx

Gruzd, A., \& Mai, P. (2020). Going viral: How a single tweet spawned a COVID-19 conspiracy theory on Twitter. Big Data \& Society, 7(2). https://doi.org/10.1177/2053951720938405

Henrich, J., Heine, S. J., \& Norenzayan, A. (2010). The weirdest people in the world? Behavioral and Brain Sciences, 33(2-3), 61-83. https://doi.org/10.1017/S0140525X0999152X

Hughes, S., \& Machan, L. (2021). It's a conspiracy: Covid-19 conspiracies link to 
psychopathy, Machiavellianism and collective narcissism. Personality and Individual Differences, 171, 110559. https://doi.org/10.1016/j.paid.2020.110559

Imhoff, R., \& Lamberty, P. (2020). A Bioweapon or a Hoax? The Link Between Distinct Conspiracy Beliefs About the Coronavirus Disease (COVID-19) Outbreak and Pandemic Behavior. Social Psychological and Personality Science. https://doi.org/10.1177/1948550620934692

Jolley, D., \& Douglas, K. M. (2017). Prevention is better than cure: Addressing anti-vaccine conspiracy theories. Journal of Applied Social Psychology, 47(8), 459-469. https://doi.org/10.1111/jasp.12453

Jost, J. T., Glaser, J., Kruglanski, A. W., \& Sulloway, F. J. (2003). Political conservatism as motivated social cognition. Psychological Bulletin, 129(3), 339-375. https://doi.org/10.1037/0033-2909.129.3.339

Krizan, Z., \& Herlache, A. D. (2018). The narcissism spectrum model: A synthetic view of narcissistic personality. Personality and Social Psychology Review, 22(1), 3-31. https://doi.org/10.1177/1088868316685018 Kosterman, R., \& Feshbach, S. (1989). Toward a measure of patriotic and nationalistic attitudes. Political psychology, 257-274. https://doi.org/10.2307/3791647

Lantian, A., Muller, D., Nurra, C., Klein, O., Berjot, S., \& Pantazi, M. (2018). Stigmatized beliefs: Conspiracy theories, anticipated negative evaluation of the self, and fear of social exclusion. European Journal of Social Psychology, 48(7), 939-954. https://doi.org/10.1002/ejsp.2498

Leach, C. W., Van Zomeren, M., Zebel, S., Vliek, M. L., Pennekamp, S. F., Doosje, B., ... \& Spears, R. (2008). Group-level self-definition and self-investment: a hierarchical 
(multicomponent) model of in-group identification. Journal of Personality and Social Psychology, 95(1), 144. https://doi.org/10.1037/0022-3514.95.1.144

León-Medina, F. J., Tena-Sánchez, J., \& Miguel, F. J. (2019). Fakers becoming believers: how opinion dynamics are shaped by preference falsification, impression management and coherence heuristics. Quality \& Quantity, 1-28. https://doi.org/10.1007/s11135-019$\underline{00909-2}$

Lincoln, M. (2020, September 15). Study the role of hubris in nations' COVID-19 response. Nature World View. https://www.nature.com/articles/d41586-020-02596-8

Maas, C. J., \& Hox, J. J. (2005). Sufficient sample sizes for multilevel modeling. Methodology. 1(3), 86-92. https://doi.org/10.1027/1614-2241.1.3.86

Marinthe, G., Brown, G., Delouvée, S., \& Jolley, D. (2020). Looking out for myself: Exploring the relationship between conspiracy mentality, perceived personal risk, and COVID-19 prevention measures. British Journal of Health Psychology. https://doi.org/10.1111/bjhp.12449

Marchlewska, M., Cichocka, A., Jaworska, M., Golec de Zavala, A., \& Bilewicz, M. (2020). Superficial ingroup love? Collective narcissism predicts ingroup image defense, outgroup prejudice, and lower ingroup loyalty. British Journal of Social Psychology, 59(4), 857875. https://doi.org/10.1111/bjso.12367

Marchlewska, M., Cichocka, A., Łozowski, F., Górska, P., \& Winiewski, M. (2019). In search of an imaginary enemy: Catholic collective narcissism and the endorsement of gender conspiracy beliefs. The Journal of Social Psychology, 159(6), 766-779. https://doi.org/10.1080/00224545.2019.1586637 
Marchlewska, M., Cichocka, A., Panayiotou, O., Castellanos, K., \& Batayneh, J. (2018). Populism as identity politics: Ingroup disadvantage, collective narcissism and support for populism. Social Psychological and Personality Science, 9(2), 151-162. https://doi.org/10.1177/1948550617732393

Mosleh, M., Pennycook, G., \& Rand, D. G. (2020). Self-reported willingness to share political news articles in online surveys correlates with actual sharing on Twitter. PLOS ONE, 15(2): e0228882. https://doi.org/10.1371/journal.pone.0228882

Nera, K., Wagner-Egger, P., Bertin, P., Douglas, K., \& Klein, O. (2021). A PowerChallenging Theory of Society, or a Conservative Mindset? Upward and Downward Conspiracy Theories as Ideologically Distinct Beliefs. European Journal of Social Psychology. https://doi.org/10.1002/ejsp.2769 Nielsen, M., Haun, D., Kärtner, J., \& Legare, C. H. (2017). The persistent sampling bias in developmental psychology: A call to action. Journal of experimental child psychology, 162, 31-38. doi:https://doi.org/10.1016/j.jecp.2017.04.017

Nowak, B., Brzóska, P., Piotrowski, J., Sedikides, C., Żemojtel-Piotrowska, M., \& Jonason, P. K. (2020). Adaptive and maladaptive behavior during the COVID-19 pandemic: The roles of Dark Triad traits, collective narcissism, and health beliefs. Personality and Individual Differences, 167, 110232. https://doi.org/10.1016/j.paid.2020.110232

Pennycook, G., Cheyne, J. A., Barr, N., Koehler, D. J., \& Fugelsang, J. A. (2015). On the reception and detection of pseudo-profound bullshit. Judgement and Decision Making, 10(6), 549-563. https://doi.org/10.1037/t52525-000 
Pennycook, G., McPhetres, J., Zhang, Y., Lu, J. G., \& Rand, D. G. (2020). Fighting COVID-19 misinformation on social media: Experimental evidence for a scalable accuracy-nudge intervention. Psychological Science, 31(7), 770-780. https://doi.org/10.1177/0956797620939054

Primi, C., Morsanyi, K., Chiesi, F., Donati, M. A., \& Hamilton, J. (2016). The development and testing of a new version of the cognitive reflection test applying item response theory (IRT). Journal of Behavioral Decision Making, 29(5), 453-469. https://doi.org/10.1002/bdm.1883

Postmes, T., Haslam, S. A., \& Jans, L. (2012). A single-item measure of social identification: Reliability, validity, and utility. British Journal of Social Psychology, 52(4), 597-617. https://doi.org/10.1111/bjso.12006

Scherbaum, C. A., \& Pesner, E. (2019). Power analysis for multilevel research. In S. E. Humphrey \& J. M. LeBreton (Eds.), The Handbook of Multilevel Theory, Measurement, and Analysis (pp. 329-352). American Psychological Association. https://doi.org/10.1037/0000115-015

Sternisko, A., Cichocka, A., \& Van Bavel, J. J. (2020). The dark side of social movements: Social identity, non-conformity, and the lure of conspiracy theories. Current Opinion in Psychology, 35, 1-6. https://doi.org/10.1016/j.copsyc.2020.02.007

Szaszi, B., Szollosi, A., Palfi, B., \& Aczel, B. (2017). The cognitive reflection test revisited: exploring the ways individuals solve the test. Thinking \& Reasoning, 23(3), 207-234. https://doi.org/10.1080/13546783.2017.1292954 
Lawson, M. A., Larrick, R. P., \& Soll, J. B. (2020). Comparing fast thinking and slow thinking: The relative benefits of interventions, individual differences, and inferential rules. Judgment \& Decision Making, 15(5).

Uscinski, J. E., Enders, A. M., Klofstad, C., Seelig, M., Funchion, J., Everett, C., Wuchty, S., Premaratne, K., \& Murthi, M. (2020). Why do people believe COVID-19 conspiracy theories? Harvard Kennedy School Misinformation Review, 1-12. https://doi.org/10.37016/mr-2020-015

Van Bavel, J.J., Cichocka, A., Capraro, V., Sjåstad, H., Nezlek, J.B., Pavlović T., Alfano A., Gelfand, M.J., Azevedo, F., Birtel M.D., Cislak, A., Lockwood, P., Ross, R. M., Stoyanova, K.K., Abts, K., Amodio, D.M., Apps, M. A.J., Aruta, J.J.B.R., Besharati, S., ..., Boggio, P. (2020). National identity predicts public health support during a global pandemic. Manuscript submitted for publication.

Van Bavel, J. J., Harris, E. A., Pärnamets, P., Rathje, S., Doell, K., \& Tucker, J. A. (2020). Political psychology in the digital (mis) information age: A model of news belief and sharing. Social Issues and Policy Review, 5(1), 83 -113. https://doi.org/10.1111/sipr.12077

Van Bavel, J. J., \& Pereira, A. (2018). The partisan brain: An identity-based model of political belief. Trends in Cognitive Sciences, 22(3), 213-224.

van der Linden, S., Panagopoulos, C., Azevedo, F., \& Jost, J. T. (2020). The paranoid style in American politics revisited: an ideological asymmetry in conspiratorial thinking. Political Psychology. https://doi.org/10.1111/pops.12681 
van Prooijen, J. W., Krouwel, A. P., \& Pollet, T. V. (2015). Political extremism predicts belief in conspiracy theories. Social Psychological and Personality Science, 6(5), 570-578. https://doi.org/10.1177/1948550614567356

van Prooijen, J. W., \& Song, M. (2020). The cultural dimension of intergroup conspiracy theories. British Journal of Psychology. https://doi.org/10.1111/bjop.12471

Vosoughi, S., Roy, D., \& Aral, S. (2018). The spread of true and false news online. Science, 359(6380), 1146-1151. https://doi.org/10.1126/science.aap9559

Wood, M. J. (2018). Propagating and debunking conspiracy theories on Twitter during the 20152016 Zika virus outbreak. Cyberpsychology, Behavior, and Social Networking, 21(8), 485-490. https://doi.org/10.1089/cyber.2017.0669

World Health Organization (2020, September 23). Managing the COVID-19 infodemic: Promoting healthy behaviours and mitigating the harm from misinformation and disinformation. https://www.who.int/news/item/23-09-2020-managing-the-covid-19infodemic-promoting-healthy-behaviours-and-mitigating-the-harm-from-misinformationand-disinformation

Zmigrod, L., Rentfrow, P. J., \& Robbins, T. W. (2018). Cognitive underpinnings of nationalistic ideology in the context of Brexit. Proceedings of the National Academy of Sciences, 115(19), E4532-E4540. 